\title{
A Stone Alabastron in the J. Paul Getty Museum and Its Mediterranean Context
}

\author{
Jorrit M. Kelder, Laurent Bricault, and Rolf M. Schneider
}

\section{Description}

The J. Paul Getty Museum has in its possession a damaged alabastron with an anthropomorphic top (fig. 1). ${ }^{1}$ The Getty alabastron was published by Sandra Knudsen Morgan, who described it as "an alabaster scent bottle" that is

carved in one piece with a rounded bottom and is shaped on the upper front in the form of the torso, head, and arms of a woman, with the flaring mouth of the vase on top of her head. The white alabaster is covered with a yellowish patina with some incrustation. The right side and part of the back are severely damaged, the right ear and cheek missing. The lip of the flask was broken and repaired in one place. ${ }^{2}$

The Getty alabastron has a total height of $23.2 \mathrm{~cm}$ and a maximum width of $4.5 \mathrm{~cm}$; the diameter of the rim is $3.5 \mathrm{~cm}$. Sporting a nemes-like veil and a tight-fitting garment, the figure reflects contemporary Egyptian sculpture, but certain details, such as the large eyes, betray Cypriot, Phoenician, and/or Greek influence. Despite the overt Egyptianizing style of the vessel, the overall impression of this alabastron is one of cultural and stylistic hybridity.

\section{Shapes, Materials, Distribution}

Alabastra are first found in Egypt from the end of the Middle Kingdom (ca. 1800 BCE) until the late New Kingdom (ca. 1100 BCE). They usually have a globular to torpedo-shaped body with a rounded base, sometimes with a distinct ridge just below the narrow neck. The mouth is normally disc shaped and notably broader than the neck. There are variations, however, and squat and bag-shaped alabastra are also known, especially in the Late Bronze Age Aegean and in Archaic Corinth. After an apparent yet unexplained gap in the eleventh to ninth centuries BCE, the production of alabastra was resumed in the late eighth century вСЕ. Examples dating to this time are known from Egypt and, almost simultaneously, in Assyria and Phoenicia. Although these alabastra were traditionally made in gypsum or travertine (often referred to as “alabaster”), ${ }^{3}$ early

Getty Research Journal, no. 10 (2018): 1-16 (C) 2018 Jorrit M. Kelder, Laurent Bricault, and Rolf M.Schneider 


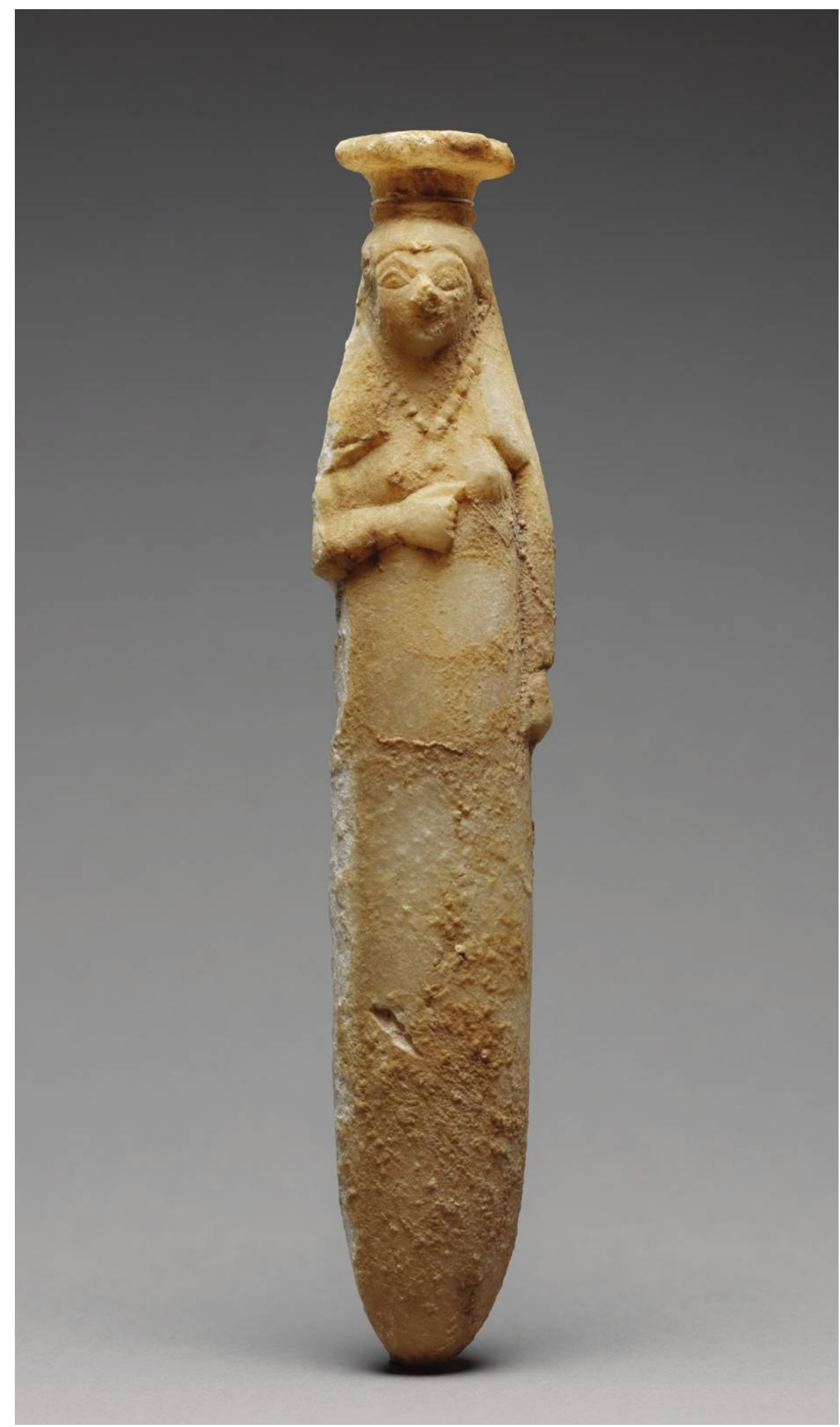

Fig. 1. Anthropomorphic alabastron, Naucratis or Cyprus, ca. 575-550 вСE, alabaster, h.: $23.2 \mathrm{~cm}$. Malibu, J. Paul Getty Museum, Villa Collection, 78.AA.306.

This content downloaded from 132.229.195.219 on February 19, 2018 01:27:54 AM All use subject to University of Chicago Press Terms and Conditions (http://www.journals.uchicago.edu/t-and-c). 
examples of other costly materials, such as glass and silver, are also known. ${ }^{4}$ In the seventh and sixth centuries BCE, the alabastron became more ubiquitous and is found in the Greek world, where it rapidly gained popularity with Corinthian and later Athenian potters, as well as in Anatolia and Etruria (from which the earliest examples seem to stem from the late seventh-century-вСE Tomb of Isis, as discussed below). Coinciding with this widening distribution of the alabastron, artists (no doubt prompted by their patrons) appear to have experimented with new shapes and materials, such as faience, precious metals, and stone. Among the novel shapes that appear from the seventh century BCE onward is the alabastron with an anthropomorphic top, to our knowledge exclusively in the shape of a woman. ${ }^{5}$ The Getty alabastron is a fine example of this new shape.

This new type of alabastron is of interest for a variety of reasons. Although the corpus of such alabastra is relatively small (we know of some thirty-five stone objects, and just under twenty additional terracotta pieces), their distribution is remarkably widespread and includes find spots on Rhodes as well as in Egypt, Etruria, and Anatolia. ${ }^{6}$ This distribution overlaps with that of the more traditional globular and torpedo-shaped alabastra, but unlike those vessels (which remained popular through the Hellenistic period), anthropomorphic alabastra are known only from seventh- and sixth-centuryBCE contexts. Anthropomorphic alabastra also stand out because of their morphological diversity, an observation that leads one to suspect that there were probably several workshops that produced these vessels. ${ }^{7}$ What we have, then, is a small number of stone anthropomorphic alabastra from the seventh and sixth centuries BCE, which were likely made by different workshops and which have been found at various sites in the Mediterranean. We should now consider the questions of where, by whom, and for whom these remarkable alabastra were made, and which female figure they represent. We will first address the question of origin.

\section{International Origins}

As noted above, the shape and pose of the female figure of the Getty alabastron clearly derives from Egyptian prototypes. The headdress, regardless of whether it was meant to represent a Greek himation, is clearly modeled on the Egyptian nemes, which characteristically leaves the ears uncovered while at the same time covering most or all of the figure's hair. Her pose, with the left arm held straight down along the body and the right arm bent horizontally under the breasts, resembles Egyptian sculpture, but it is also well known from contemporary Archaic Greek and Cypriot sculpture. ${ }^{8}$ Despite the overt Egyptian design, certain details, especially in the face, such as the wide, staring eyes, suggest that the Getty alabastron was not produced in an Egyptian workshop. P. J. Riis had already made this observation in his earlier study on similar anthropomorphic alabastra, proposing that they may have been made by Cypriot craftsmen possibly working in the Nile Delta. ${ }^{9}$ Noting the paucity of similar pieces on Cyprus itself, however, Morgan submits that the Getty alabastron might instead have been made in Naucratis, an important Greek settlement in the Egyptian Nile Delta. ${ }^{10}$ 

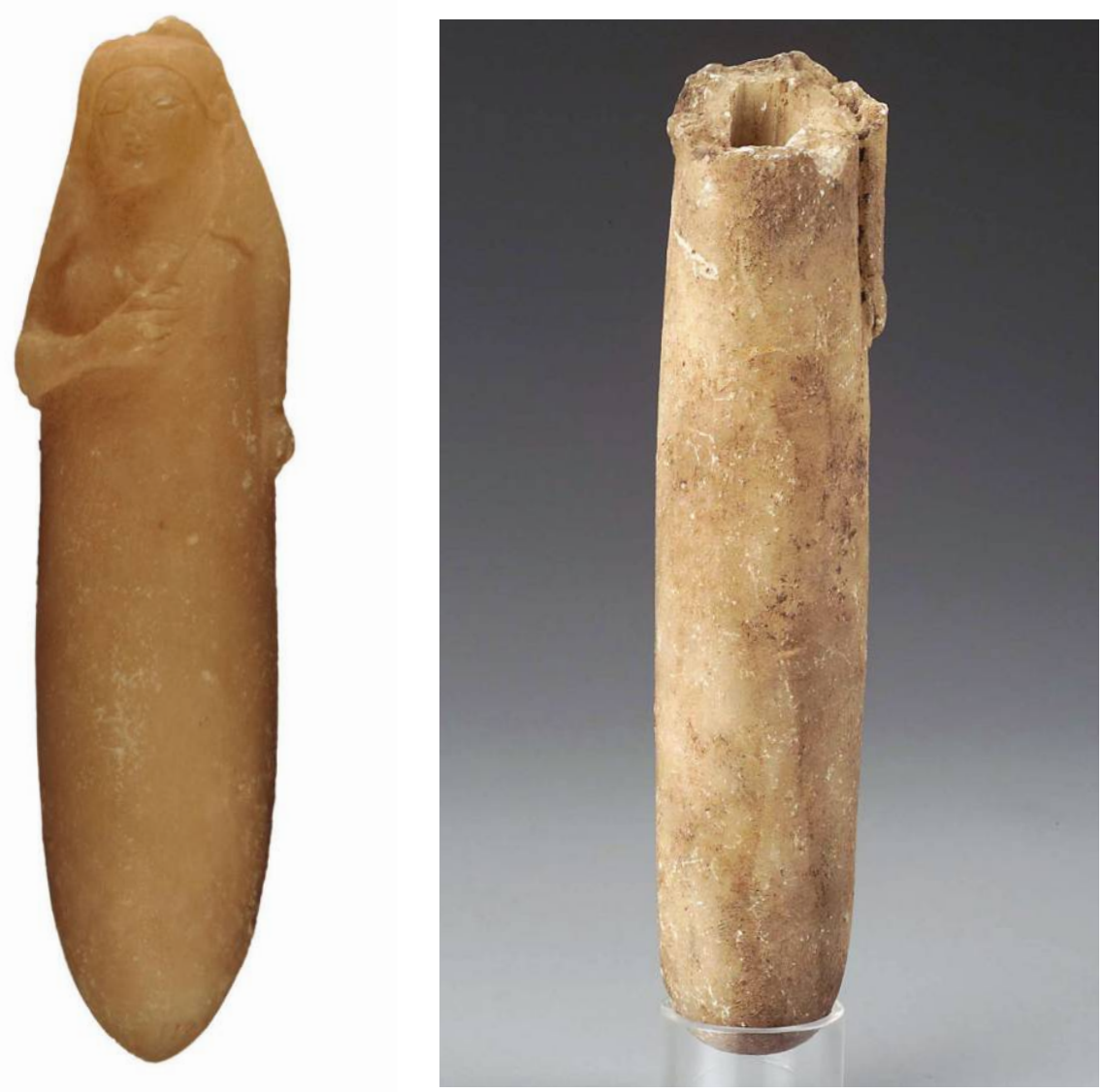

Fig. 2. Stone alabastron from the sanctuary of Aphrodite, Naucratis, ca. 575-550 BCE, alabaster, h.: 17.2 cm. London, British Museum, 1888,0601.15. Image: (c) Trustees of the British Museum.

Fig. 3. Stone alabastron fragment from the temple of Aphrodite, Naucratis, ca. 330-305 BCE, alabaster, h.: 9.6 cm. Boston, Museum of Fine Arts, 88.738. Image courtesy Museum of Fine Arts, Boston.

There can be no doubt that stone alabastra were produced at Naucratis. Indeed, the archaeologist W. M. Flinders Petrie, who excavated the site, reported "many thousands of alabaster drill cores from tubular drilling... and fragments of parts of alabaster vases in course of manufacture."11 While these fragments may well belong to the more regular globular to torpedo-shaped alabastra that were also popular at this time, at least four anthropomorphic alabastra have been found at Naucratis, proving that the anthropomorphic alabastron was, at the very least, known at that site. Two of these alabastra (figs. 2, 3) came from the sanctuary of Aphrodite, ${ }^{12}$ and a third came from the sanctuary of Apollo (fig. 4) ${ }^{13}$ All three contexts date to the late Saite Dynasty (early to mid-sixth century вСE), and thus belong to a period of significant Greek presence in Naucratis. A fourth object, a fragment of a head that is now in the Bolton Museum, was also found in Naucratis, though its exact context is not known (fig. 5). ${ }^{14}$ Like the above-mentioned other alabastra found at Naucratis, however, this fragment is dated on stylistic grounds to the second quarter of the sixth century BCE. 

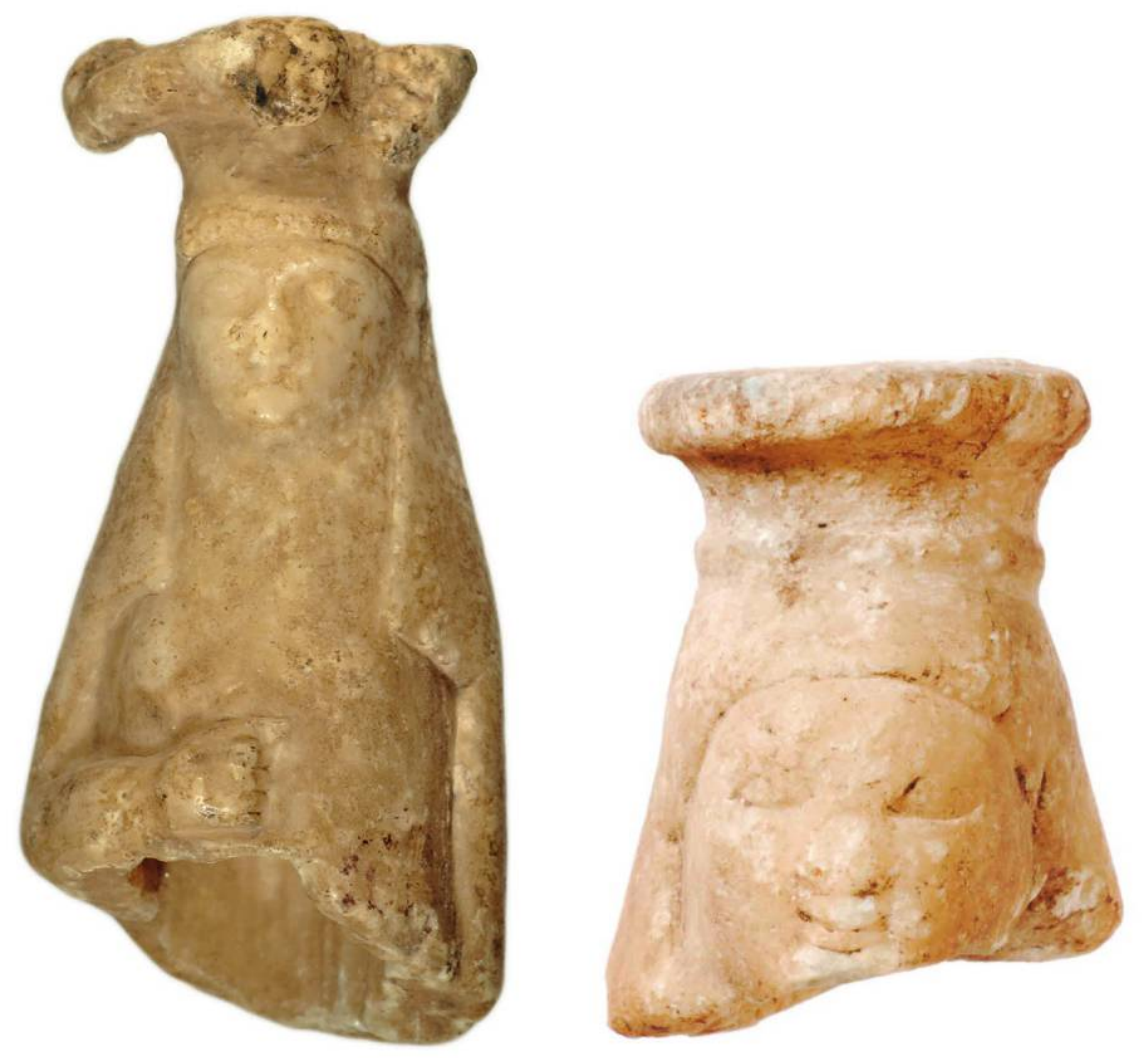

Fig. 4. Stone alabastron fragment from the sanctuary of Apollo, Naucratis, ca. 575-550 вCE, alabaster, h.: 8.4 cm. London, British Museum, 1886,0401.1393. Image: (c) Trustees of the British Museum.

Fig. 5. Stone alabastron fragment from Naucratis, ca. 575-55О вGE, alabaster, h.: $4.2 \mathrm{~cm}$. Bolton, England, Bolton Museum, 1966.112.A. Image: @ Bolton Library and Museum Service.

While Morgan's identification of Naucratis as a likely production center for at least some of the anthropomorphic alabastra is, therefore, entirely plausible, some caution is appropriate nevertheless. There are differences among the anthropomorphic alabastra from Naucratis, which may or may not suggest that they were made by different craftsmen, possibly operating in different workshops. The fragmentary head from the Bolton Museum (see fig. 5), for example, has its ears covered by the veil, whereas the alabastra in the British Museum have their ears uncovered. Moreover, in contrast to the almost complete alabastron from the British Museum (see fig. 2), the fragment in the same museum (see fig. 4) shows no traces of a modeled necklace and has a notably longer headdress. As has already been observed by Morgan, ${ }^{15}$ the nearly complete vessel from the British Museum (see fig. 2) seems to be the closest parallel to the Getty alabastron in terms of shape, material, proportions, and iconography, though even here there are differences. The right hand of the Getty alabastron is shown as a clenched fist with the thumb stretched upward, whereas the right hand of the specimen from the British 
Museum seems to be holding an unidentified object (maybe a pendant hanging from the necklace, seeing as the Getty alabastron shows such a pendant). It is impossible to establish whether any or all of these seemingly minor differences are meaningful when it comes to identifying their workshop(s), let alone specific craftsmen. Nonetheless, these variations serve as a warning against the assumption that all four anthropomorphic alabastra that were found at Naucratis were also made at that place; some may have been imported from other centers in Egypt or elsewhere in the Mediterranean.

That these considerations are not merely academic but have some bearing on sixth-century-вСE reality can be demonstrated by looking at a closely related class of objects: namely, terracotta anthropomorphic alabastra. One such terracotta vessel, found in a tomb at Kameiros on Rhodes (fig. 6), bears a particularly close resemblance to the Getty alabastron. ${ }^{16}$ The figure on this vessel wears a similar headdress that leaves the ears uncovered. The general shape and pose also compares well to the Getty alabastron, as does the presence of a necklace in raised relief. But there are also differences, such as the material (terracotta rather than stone), the quality of the modeling (in particular, the arms of the Kameiros piece, which are less pronounced than those of the Getty alabastron, though these differences could be due to the different materials), and the presence of a bird in the right hand of the woman on the Kameiros alabastron (a feature that it shares with a number of other, similar alabastra, such as a piece that is said to have been found at Corinth [see note 6]). Despite these differences, it is clear that such pieces as the terracotta alabastron from Kameiros belong to the same cultural sphere as the Getty alabastron, and it would be interesting to know where that particular piece was manufactured. It is therefore a pity that, to our knowledge, the clay of the Kameiros piece has not been chemically analyzed. Consequently, it is impossible to state with certainty where it was made. In general, it is assumed that it was made by an "East Greek" workshop-a rather vague designation that includes Rhodes itself, along with various other isles in the Aegean, as well as the Anatolian west coast.

This is interesting, for we know that at or near Miletus, the major "East Greek" center of the Archaic Greek world which had particularly close historical ties to Naucratis, ${ }^{17}$ terracotta anthropomorphic alabastra were made. Moreover, these vessels appear to have been exported to, of all places, Naucratis, where at least twelve pieces of terracotta anthropomorphic alabastra have been found. ${ }^{18}$ This includes the head of an alabastron that was purchased by Petrie from his workmen and dates to the second half of the sixth century вСЕ (fig. 7). Although there are some notable differences, such as hairstyle, among the Milesian terracotta alabastra from Naucratis, the terracotta alabastron from Kameiros, and the stone vessels from Naucratis, we are confronted with the curious situation of finding imported terracotta anthropomorphic alabastra at Naucratis, a site that itself is known to have been a major producer of stone alabastra. ${ }^{19}$

In sum, it seems nearly impossible to establish with any certainty the origin of the stone anthropomorphic alabastra at Naucratis and the Getty alabastron. Microscopic analysis of the stone may help in identifying a source, but even here, the results are not 

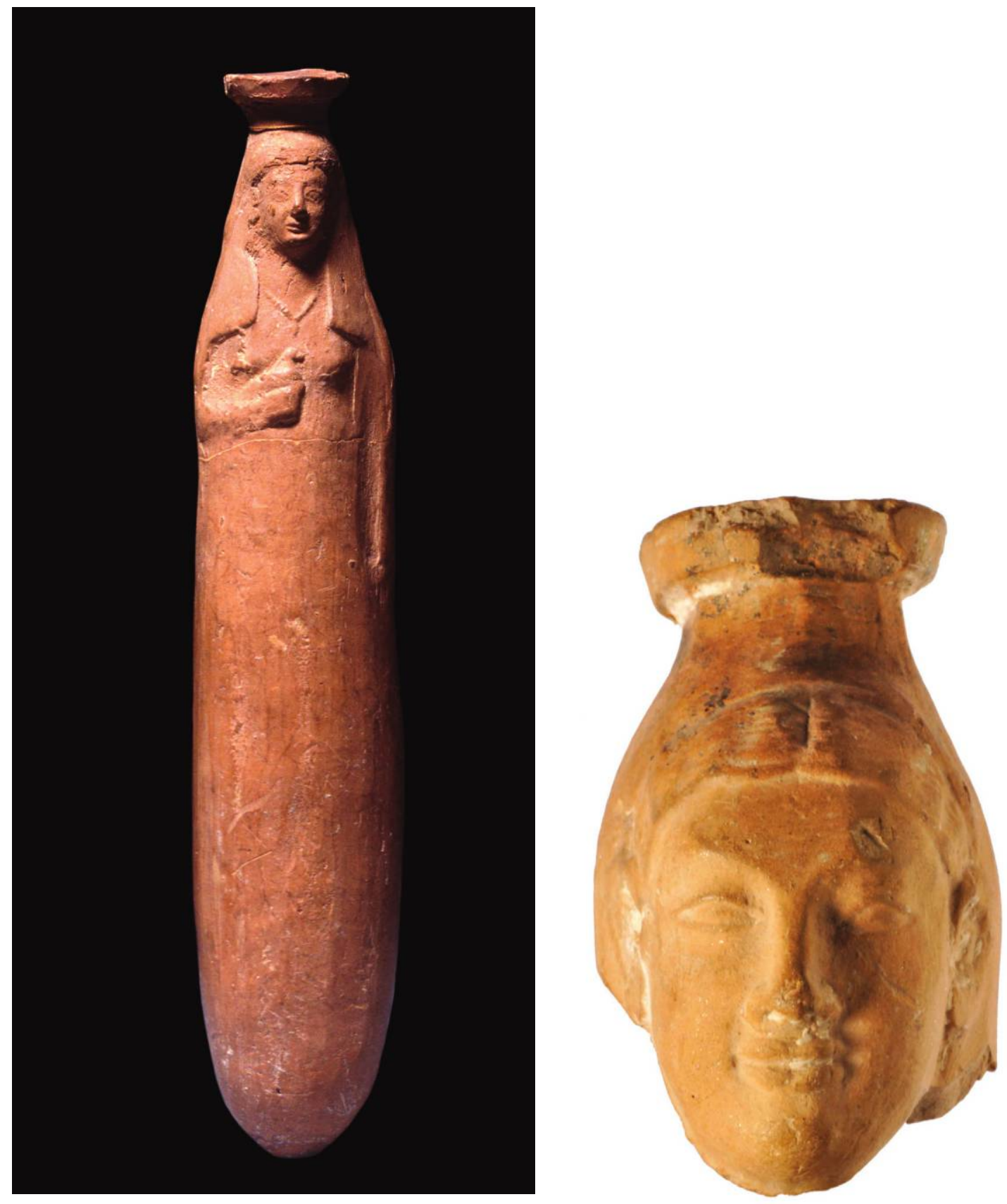

Fig. 6. Terracotta alabastron from Kameiros on Rhodes, ca. 550 вGE, terracotta, h.: $21.4 \mathrm{~cm}$. London, British Museum, 1861,1024.7. Image: (C) Trustees of the British Museum.

Fig. 7. Terracotta alabastron fragment from Naucratis, ca. late $500 \mathrm{~s}$ BCE, terracotta, h.: $5 \cdot 7 \mathrm{~cm}$. London, British Museum, 1886,0401.1400. Image: @ Trustees of the British Museum.

This content downloaded from 132.229.195.219 on February 19, 2018 01:27:54 AM

All use subject to University of Chicago Press Terms and Conditions (http://www.journals.uchicago.edu/t-and-c). 
always conclusive. For example, C. H. Roosevelt notes that travertine from a quarry near the Lydian capital of Sardis, which we know was used for the production of stone vessels in that region, is micro- and macroscopically identical to various types of Egyptian travertine. ${ }^{20}$ Thus it is possible that some, or all four, of the stone anthropomorphic alabastra at Naucratis were in fact Milesian imports. In view of the similarities among the Getty alabastron and the stone and terracotta alabastra that were found at Naucratis (esp. fig. 2) and Kameiros, an "East Greek" - possibly Milesian — origin for the Getty piece seems plausible, though it cannot be proven. Regardless of these details, the difficulties in identifying the vessel's origins highlight the hybrid, "international" qualities of the Getty alabastron and others of its type. Indeed, Roosevelt has persuasively argued that the proliferation of alabastra in general (not only the anthropomorphic type) could be considered an "orientalizing" phenomenon. ${ }^{21}$ In that sense, the Getty alabastron can be understood as an icon of increasing political, religious, and cultural interaction in especially the eastern and central Mediterranean during the seventh and sixth centuries BCE, and the emergence of what has been coined (albeit in a Late Bronze Age context) an "International Style."22

\section{Use, Connotation, Identity}

In view of the significant geographical spread of anthropomorphic alabastra and the sheer hybridity of these objects in terms of shape (a combination of a vessel and a figurine) and style, it is probably not surprising that these vessels are found in a variety of contexts. In Naucratis, as we have seen, one vessel was found in the area of the temple of Apollo, whereas two other pieces were recovered from the temple of Aphrodite. The terracotta alabastron from Kameiros on Rhodes and the stone anthropomorphic alabastra from Etruria, on the other hand, were found in tombs. Despite these differences, however, it may be possible to approximate some of the connotations that these vessels carried within the various communities that deposited them. Roosevelt notes that alabastra in Western Anatolia-regardless of whether they were anthropomorphic or not-appear to have been used predominantly in a funerary setting, and he suggests that their use may ultimately derive from their association with the Egyptian rituals of the New Year and related concepts of renewal and rebirth. ${ }^{23}$ Moreover, he suggests that the clear preference for this particular shape by Lydia's elite, as well as the use of travertine, may relate to associations with "royalty and Egyptian prototypes and their very orientality, marked out most clearly by their material." 24

As we have seen above, the alabastron did indeed have a distinguished pedigree. Early Assyrian examples were explicitly inscribed as prized royal possessions, while during the Twenty-Fifth to Twenty-Seventh Dynasties in Egypt, stone alabastra may have been used in the context of royal gift exchange. ${ }^{25}$ During the Persian period, at least, stone alabastra were clearly prized by the Persian king and the empire's elite. This is indicated by the occurrence of a number of such vessels, bearing the names of Persian kings, at various sites in the Levant, the Persian heartland, and Anatolia—-such as a stone alabastron 
inscribed with the name of King Xerxes, which was found at the tomb of Maussollos in Halikarnassos. ${ }^{26}$ It is not impossible, and is indeed quite likely, that alabastra, and the much rarer and more Egyptianizing type of anthropomorphic alabastra in particular, may have carried similar (originally Egyptian) connotations among the elites in other parts of what was, by the sixth century вСE, an increasingly connected eastern and central Mediterranean world. This would not only mesh well with the funerary use of these vessels in Etruria and Rhodes but may also tally with the deposition of anthropomorphic alabastra in the temple of Aphrodite at Naucratis.

This brings us to the delicate question of the identity - or identities - of the anthropomorphic alabastra. As we have seen, it is likely that, during the sixth and fifth centuries BCE, anthropomorphic alabastra were produced in a number of workshops throughout the ancient world. Some of these workshops produced vessels that appear more "local" in style, such as the stone alabastra from the Isis Tomb at Vulci (fig. 8) or the anthropomorphic alabastron from Gordion, whereas others seemed to have adhered more closely to the style of a, presumably Egyptian(izing), prototype. Nevertheless, in view of the fact that all of the anthropomorphic alabastra clearly show a female figure, and since this female figure, regardless of her place of manufacture or deposition, seems to adhere to the same overall dress code (which included a nemes-like veil or himation, or a similarly shaped wig or hairdo; a tightly cut garment that shows the female form or leaves the breasts bare; and a necklace, with or without pendant), there is the suggestion that we are dealing with a fairly specific figure here. Because of the clear Egypt-inspired appearance, as well as the aforementioned Egyptian connotations these vessels seem to have had, it seems most likely that we should look to the Land of the Nile for the origins of this figure.

We have seen how anthropomorphic alabastra were likely used in the context of fertility-related cultic activity, either in funerary settings in, for example, Anatolia, Etruria, and the Greek world, or, at least at Naucratis, in sanctuaries such as those of Apollo and Aphrodite. Two Egyptian deities seem to fit this bill particularly well: the goddesses Hathor and Isis. Hathor, in Pharaonic times regularly portrayed as a cow or as a human with bovine elements (such as horns or, in Ptolemaic times, cow ears), was normally seen as the goddess of motherhood and childbirth, although she is also known in other capacities, including as "Mistress of the West" (that is, the world of the dead) and as a remarkably bloodthirsty warrior-like goddess. Herodotus identifies her as the Egyptian version of the Greek goddess Aphrodite, and certain aspects of her iconography appear to have had a ready appeal elsewhere in the eastern Mediterranean.

This was especially the case on Cyprus, where we find vases with painted Hathoric heads in the necropolis and citadel of Amathus, as well as numerous examples of anthropo-bovine "Hathor capitals" and Hathor heads in contemporary (sixth century BCE) sculpture, mostly in palatial contexts or at sanctuaries of the Cypriot Aphrodite. ${ }^{27}$ The fact that there is no indication for a real Hathor cult on the island at that time suggests, as Anja Ulbrich has argued, that the image of the goddess was adopted 


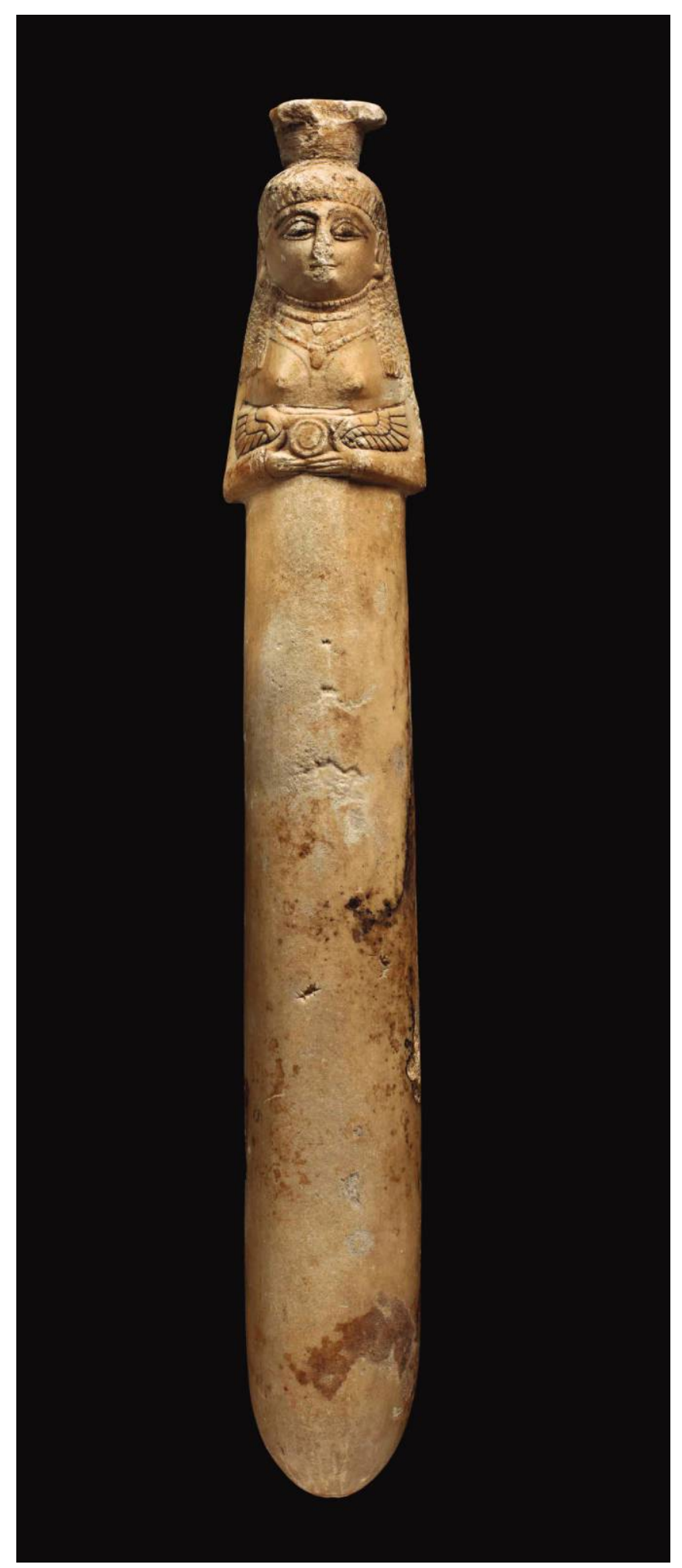

Fig. 8. Stone alabastron from the so-called Isis Tomb at Vulci, Etruria, ca. 625-550 вGE, gypsum,

h.: 44 cm. London, British Museum, 1850,0227.2. Image: ( ) Trustees of the British Museum.

This content downloaded from 132.229.195.219 on February 19, 2018 01:27:54 AM

All use subject to University of Chicago Press Terms and Conditions (http://www.journals.uchicago.edu/t-and-c). 
and regarded as an appropriate image for the Cypriot Aphrodite. ${ }^{28}$ Interestingly, this "Egyptian iconography” for the Cypriot Aphrodite is likely to have reached the island via Phoenicia, where the image had been adopted and used in association with Astarte. ${ }^{29}$ This highlights the point that even what appears to us as overtly Egyptian iconography, such as the Hathor heads on Cyprus or, indeed, the anthropomorphic Getty alabastron, may have had far more diverse and complex connotations to the ancients. ${ }^{30}$ Those that beheld such vessels, depending on their cultural origins, could read the image as Isis, Hathor, Aphrodite, Astarte, or even other deities, thus making such anthropomorphic alabastra universally appealing.

To complicate matters even more, there is ample evidence for syncretism between Hathor and another Egyptian goddess, Isis, in Saite Egypt itself. Isis is attested from the late Old Kingdom onward, and she was initially represented as the divine wife and protector of the deceased king; the name "Aset," Graecized as "Isis," translates as "throne." As such, she was also associated with royal mortuary cults, as protector of the canopic jars. Over the course of Pharaonic history, however, her role in the Egyptian pantheon changed, and she became progressively more popular and prominent until, during the Late Period and especially under the kings of the Twenty-Sixth, or Saite, Dynasty, her cult came to dominate Egyptian religious life. Isis's moves up through the ranks, which involved her usurping Hathor's original position as mother of the god Horus, is reflected in her iconography. Isis was traditionally depicted as a woman wearing a long sheath dress and usually carrying a crown in the shape of a throne, a reference to her function as protector of the king. ${ }^{31}$ As a result of an increasing syncretism of Hathor and Isis from the Saite period onward, however, the iconography of these two deities becomes murky, and we thus find depictions of - apparently-Isis suckling Horus while wearing a crown with two bovine horns.

This syncretism between two Egyptian goddesses and their Greek, Cypriot, and Phoenician equivalents - and there are more examples of divine "mergers" in the ancient world - may perhaps point us toward a tentative identification of the figures on the anthropomorphic alabastra. Instead of attempting to identify a specific deity, it is perhaps better to suggest that the figures on the alabastra were recognized by all who saw and used these vessels as a representation not so much of a local goddess of fertility and rebirth but rather as a "universal" representation of such powers. Of course, this does not mean that the various Mediterranean elites who commissioned and deposited anthropomorphic alabastra in tombs or at sanctuaries were oblivious to the names, functions, and relevant rites surrounding Hathor and Isis in Egypt itself. Indeed, the overt Egyptian appearance of the anthropomorphic alabastra, even those that were definitely not made in Egypt, such as the pieces found in Etruria; see, for example, figure 8, which clearly points toward an awareness of, and indeed demonstrates a clear effort to associate the use of such vessels with, Egyptian or at the very least exotic practice. ${ }^{32}$ Moreover, there is some very good evidence for the conscious adoption of aspects of Egyptian funerary practices in Etruria, where the woman buried in the Isis Tomb at Caere was wearing a beaded pectoral imported from 
Egypt and was interred not only with Egyptian-style alabastra but also with various New Year's flasks inscribed with hieroglyphs. Thus, it appears that these groups consciously adopted, transformed, and displayed foreign elements to accommodate local ideas about renewal and the afterlife, and in doing so augmented their own status among peers.

\section{Conclusions}

What does all this mean for the "alabaster scent bottle" in the J. Paul Getty Museum? We hope to have demonstrated that this alabastron is far more than just an "East Greek" or “Ionian” object. Stylistically, it includes elements that are Egyptian, or Egyptian inspired. At the same time, however, the alabastron is also clearly different from traditional Egyptian workmanship: the large, staring eyes can be more readily compared to contemporary Phoenician, Cypriot, and/or Greek sculpture. Through its hybrid iconography, the Getty alabastron evoked foreign-Egyptian, Cypriot, Phoenician, and/or Greek, but most importantly exotic - associations, and thus could be considered as an embodiment of the international spirit of the seventh and sixth centuries BCE. As such, the Getty alabastron may well have been the product of a Greek workshop in Naucratis, as argued by Morgan, but it could equally well have been made in Miletus, on Cyprus, or, for that matter, anywhere else in the eastern Mediterranean. In the end, it is very doubtful whether the origin of the vessel was of much consequence to the ancients. What was important was its potential to convey notions of universal power-both of the deity that adopted this international iconography and of the elite that bestowed it upon her.

Jorrit M. Kelder is an associate member in the sub-faculty of Near and Middle Eastern Studies at the University of Oxford.

Laurent Bricault is a professor of Roman history at the Université Toulouse II Jean-Jaurès, and a member of the Institut Universitaire de France.

Rolf M. Schneider is a professor emeritus of classical archaeology at Ludwig-Maximilian Universität Munich.

Notes The authors would like to thank the curators and staff at the Getty Research Institute and the Getty Villa for their help and hospitality, and especially Sara Cole for her kind help and suggestions. We are indebted to this journal's anonymous reviewer for the useful feedback and references. All remaining errors remain, of course, our sole responsibility.

1. Los Angeles, J. Paul Getty Museum, acc. no. 78.AA.306. Unknown provenance; formerly in a private collection and sold at Christie's, London, 18 November 1977; lot 373.

2. Sandra Knudsen Morgan, “An Alabaster Scent Bottle in the J. Paul Getty Museum,” J. Paul Getty Museum Journal 6/7 (1978/79): 199.

3. See Barbara G. Aston, Ancient Egyptian Stone Vessels. Materials and Forms (Heidelberg: Orientverlag, 1994), 42-44.

4. For example, a glass nahbusu — the Akkadian designation for an alabastron — was found by A. H. Layard at Nimrud and bore an inscription referring to King Sargon (ca. 722-705 BCE; now in the British Museum, acc. no. 90952), whereas an inscription on a squat alabastron from Nineveh identifies 
the vessel as a gift from King Senacherib (ca. 705-681 BCE) for one of his sons; see Austen Henry Layard, Discoveries in the Ruins of Nineveh and Babylon, with Travels in Armenia, Kurdistan and the Desert (London: Murray, 1853), 196.

5. C. H. Roosevelt, "Stone Alabastra in Western Anatolia," in New Approaches to Old Stones: Recent Studies of Ground Stone Artifacts, ed. Yorke M. Rowan and Jennie R. Ebeling (London: Routledge, 2008), 288.

6. It goes beyond the scope of this paper to present a full catalog. An initial inventory was compiled in 1956 by P. J. Riis, who reports on examples in stone from Egypt (two from Naucratis), one from Cyprus (from Tomb 283 at Amathus), Etruria (Caere, Populonia, Vulci, Chiusi, Tarquinia), Kameiros on Rhodes, and Phrygia (Gordion); P. J. Riis, "Sculptured Alabastra," Acta Archaeologica 27 (1956): 23-33. On the example from Amathus, see also Vassos Karageorghis and A. Hermary, La Nécropole d'Amathonte, tombes 113-367, Études Chypriotes IX (Nicosia: Leventis, 1987), 56. Morgan mentions an additional stone vessel from Naucratis. We know of one more alabaster anthropomorphic alabastron, which was published in an auction catalog as "Eastern Greek or Phoenician" and is said to have come from an "ancienne collection privée française," but we have not been able to establish its antiquity or provenance. In addition to these "regular" anthropomorphic alabastra, excavations at various Etruscan sites have yielded a number of peculiarly shaped alabastra, including four-headed alabastra from Populonia and Casale Marittimo; see Stefano Bruni, Etrusker in der Toskana. Etruskische Gräber der Frühzeit, exh. cat. (Hamburg: Museum für Kunst und Gewerbe Hamburg, 1987), 228-9; and Maria Raffaella Ciucccarelli, "La ceramica GrecoOrientale nell'Etruria settentrionale," $А Г \Omega Г H$, Atti della Scuola di Spezializzazione in Archeologia 1 (2004): 152, n. 134. Another stone specimen, now in the Metropolitan Museum of Art (inv. 2008.332) and said to be from Vulci, sports a four-headed pedestal; see Sybille Haynes, “An Etruscan Alabastron,” Antike Kunst 6, vol. 1 (1963):3-5. The peculiar pedestal of these vessels may point to specific local (Etruscan) traditions. In addition to stone alabastra, various terracotta specimens have been recovered throughout the Mediterranean. Morgan, “An Alabaster Scent Bottle,” and Jean Ducat, Les vases plastiques rhodiens. Archaïques en terre cuite (Paris: Boccard, 1966), 72-74, mention one from Kameiros on Rhodes (now at the British Museum; see below) that bears a particular resemblance to the Getty alabastron, one vessel that may have come from Etruria (Reynold A. Higgins, Catalogue of Terracottas, vol. 1, Greek: 730-330 BC [London: British Museum, 1954], no. 48, pl. 9), one from Gela, one from Orvieto, three (rather than the single piece listed by Ducat and Morgan) from the Temenos of Hera Limenia at Perachora (J. H. Jenkins, "The Terracottas from the Temenos of Hera Limenia," in Perachora. The Sanctuaries of Hera Akraia and Limenia, ed. T. J. Dunbabin [Oxford: Clarendon, 1940], 250-51; nos. 275, 276, and 277: pl. 112), and one from Corinth (Morgan, “An Alabaster Scent Bottle," 201n8). The alabastron that is said to come from Corinth is now in Munich (Antiquarium no. 661a) and is similar to the Getty alabastron, though it seems slightly less tubular in shape, with a relatively flat base. Moreover, the figure holds a bird in the right hand, situated just below a pendant hanging from her necklace; see M. I. Maximova, Les vases plastiques dans l'Antiquité (Epoque Archaïque), 2 vols. (Paris: Geuthner, 1927), 1:128, and 2: pl. XV; 63a, b). The list may now be complemented with some twelve mostly late sixth-century-BCE, terracotta pieces from Naucratis, which are kept in the British Museum and the Ashmolean Museum (AN 1289044001001), as well as a terracotta fragment from Lindos on Rhodes (Christian Blinkenberg, Lindos. Fouilles de l'Acropole 1902-1914, vol. 1, Les petits objets [Berlin: De Gruyter], 1931 pl. 85, no. 2114), and a possible piece from Memphis (published as Hellenistic by Sally-Ann Ashton, Petrie's Ptolemaic and Roman Memphis [London: Taylor \& Francis, 2003], 77, UC47941; non vidimus), but sixth century вСЕ according to Alexandra Villing et al., Naukratis, Greeks in Egypt (London: British Museum, 2013-15), http://www.britishmuseum.org/research/online_research_catalogues/ ng/naukratis_greeks_in_egypt.aspx. In addition, the discovery of several terracotta pieces, including an interesting group of terracotta "fusiformi" alabastra with stamped, and occasionally multiple, faces on the neck from the area of Vetulonia, suggests local production in that area; see Luca Cappuccini, "Aspetti 
economici e produttivi di Vetulonia arcaica: La 'via dei metalli' e gli alabastra fusiformi di bucchero e impasto," Studi Etruschi 76 (2014): 71-75, and figs. 3, 7, 8).

7. Riis already suggested a division into two distinct groups, which included an "Eastern Group" and a "Western Group." To our knowledge, this basic classification has not been challenged in subsequent studies, although various studies refined or expanded on his classification (for example, Haynes, "An Etruscan Alabastron,” 4). Recent finds from Etruria, especially, strongly suggest several centers of production in that region (for example, Cappucini, "Aspetti economici e produttivi di Vetulonia arcaica”).

8. For an overview of Archaic Greek korai, see, for example, Katerina Karakasi, Archaic Korai (Los Angeles: J. Paul Getty Museum, 2003); see also Rolf M. Schneider, "Korai und Kouroi. Neue Menschenbilder aus Marmor im Mittelmeerraum," in Die griechische Welt. Erinnerungsorte der Antike, ed. Elke Stein-Hölkeskamp and Karl-Joachim Hölkeskamp (Munich: Beck, 2010), 221-43; and Marion Meyer and Nora Brüggemann, Kore und Kouros. Weihegaben für die Götter (Vienna: Phoibos, 2007).

9. Riis, "Sculptured Alabastra.”

10. Morgan, "An Alabaster Scent Bottle.”

11. W. M. Flinders Petrie, Naukratis I (London: Trübner, 1886), 175.

12. This includes the aforementioned vessel, British Museum GR1888,0601.15, which, according to the painted registration on the vessel, came from context $\Phi 8$ (although the paint is vague, and it may instead be Ф5). A similar vessel, now at the Boston Museum (acc. no. 88.738), came from Ф1०. Cf. Ernest A. Gardner, Naukratis, pt. 2, 1885-6 (London: Trübner, 1888), pl. XIV, no. 11; Ursula Höckmann, Zyprisch-griechische Kleinplastik: Kouroi, andere Figuren und plastisch verzierte Gefässe (Worms: Werner, 2007), 189-90, no. N35.

13. From stratum АП 7; British Museum GR1886,0401.1393. The British Museum catalog notes that Höckmann, Zyprisch-griechische Kleinplastik, 189-90, no. N36, erroneously attributed it to the sanctuary of Aphrodite.

14. Bolton Museum, acc. no. 1966.112.A; see also Villing et al., Naukratis, Greeks in Egypt, CD 122 (phase 3).

15. Morgan, “An Alabaster Scent Bottle," 199.

16. Now at the British Museum, reg. no. 1861,1024.7. Erroneously shown by Morgan in fig. 5 (Morgan, "An Alabaster Scent Bottle," 201; should have been no. 4, which now shows a piece from the British Museum thought to have come from Etruria).

17. But note that Alexander Fantalkin persuasively argues for Lydian interest in (the foundation of) Naucratis, through its dominance over the various Ionian city-states on the west coast of Anatolia; Alexander Fantalkin, "Naukratis as a Contact Zone: Revealing the Lydian Connection,” in Kulturkontakte in antiken Welten. Vom Denkmodell zum Fallbeispiel, ed. Robert Rollinger and Kordula Schnegg (Leuven: Peeters, 2014), 27-51.

18. These fragments are now in the British Museum; details can be accessed via the online catalog, numbers D24, 25, 38, 39, 42, 44, 45, 46, 47, 48, 50, 51, 52 (D24 and D25 appear to belong to the same, apparently painted alabastron). Various other terracotta objects from Naucratis, such as figurines, appear to have been made with the same clay, and one of these objects (BM1888,0601.659) has been subjected to Neutron Activation Analysis. These results indicate an East Greek, probably Milesian origin; see R. E. Jones, Greek and Cypriot Pottery: A Review of Scientific Studies (Athens: British School at Athens, 1985), 673. They are all dated to the third quarter of the sixth century вСE- that is, slightly later than the four stone alabastra that are thus far known from Naucratis (which date to the second quarter of that century).

19. Although even here, a note of caution is in order, and we know from a fifth-century-BCE papyrus from Elephantine that ancient potters, on occasion at least, also imported specific clay (in this case from Chios) for their workshops; see Robert Rollinger, "Zu Herkunft und Hintergrund der in altorientalischen Texten genannten 'Griechen,'” in Getrennte Wege? Kommunikation, Raum und Wahrnehmung in der 
Alten Welt, ed. Robert Rollinger, Andreas Luther, and Josef Wiesehöfer (Frankfurt: Verlag Antike, 2007), 302 , and references therein. An alternative scenario may thus be that a workshop at Naucratis imported Milesian clay for the production of Egyptianizing alabastra and figurines. In view of the fact that this clay seems to have been used for a number of fairly inconspicuous figurines and plaques, which would hardly warrant the importation of specific clay, this scenario strikes us as less likely.

20. Roosevelt, "Stone Alabastra in Western Anatolia," 293.

21. Roosevelt, "Stone Alabastra in Western Anatolia," 288.

22. Roosevelt, "Stone Alabastra in Western Anatolia," 289; for Bronze Age parallels, see Marian H. Feldman, Diplomacy by Design: Luxury Arts and an "International Style" in the Ancient Near East, 14001200 BCE (Chicago: University of Chicago Press, 2006).

23. Roosevelt, "Stone Alabastra in Western Anatolia," 291.

24. Roosevelt, "Stone Alabastra in Western Anatolia," 291-92. Note that only one anthropomorphic alabastron, from a tumulus at Gordion, has so far been identified with certainty in Anatolia; Gustav Körte and Alfred Körte, Gordion. Ergebnisse der Ausgrabung im Jahre 1900 (Berlin: Reimer, 1904), 123-24. G. Hanfmann notes that the stone alabastron from the Lydian tomb 59.2 at Sardis, despite its missing top, may have been an anthropomorphic alabastron; G. Hanfmann, “Excavations at Sardis 1959," Bulletin of the American Schools of Oriental Research 157 (1960): 12.

25. Jacke Phillips, "Punt and Aksum: Egypt and the Horn of Africa,"Journal of African History 38, no. 3 (1997): 442, mentions an Egyptian alabastron from an apparently royal shaft grave at Yeha in Ethiopia, which can be dated to within the Twenty-Fifth and Twenty-Seventh Dynasties (that is, 770$404 \mathrm{BCE})$ and which may have arrived there as a royal gift.

26. For the alabastron at Halikarnassos, see Kristian Jeppesen et al., The Maussolleion at Halikarnassos: Reports of the Danish Archaeological Expedition to Bodrum, vol. 1, The Sacrificial Deposits (Copenhagen: Glydendal, 1981), 41-42. Roosevelt, “Stone Alabastra in Western Anatolia," 290, suggests that these inscribed alabastra might have been used in royal gift exchange, although the fact that some of the inscriptions specify the apparent date of the issue of the vessels rather suggests that they were used as a form of special tribute, which was sent to the court at Persepolis. (JK: pers. comm. Wouter Henkelman, (unpublished) lecture, "The Achaemenids and the Imperial Signature: Persepolis-Arachosia-Bactria," delivered at the University of California, Los Angeles, 29 April 2016.)

27. Giorgos Papantoniou, Religion and Social Transformations in Cyprus: From the Cypriot Basileis to the Hellenistic Strategos (Leiden: Brill, 2012), 270.

28. Papantoniou, Religion and Social Transformations in Cyprus, 270.

29. Anja Ulbrich, "Images of Cypriot Aphrodite in Her Sanctuaries during the Age of CityKingdoms," in Brill's Companion to Aphrodite, ed. Amy C. Smith and Sadie Pickup (Leiden: Brill, 2010), 184.

30. Egyptian culture made a notable impact on Cyprus during the sixth century, and, traditionally, this has been interpreted as archaeological evidence for the Egyptian conquest of the island under Amasis, as related by Herodotus (II.182.2) and Diodoros (I.68.6); see, for example, Einar Gjerstad, The Swedish Cyprus Expedition, vol. 4, pt. 2, The Cypro-Geometric, Cypro-Archaic and Cypro-Classical Periods (Stockholm: Swedish Cyprus Expedition, 1948), 467n3. This view, however, has been challenged in more recent publications, and whilst there may have been a certain degree of, perhaps nominal, Saite control over Cyprus, a full-blown Egyptian conquest of the island is now generally considered unlikely; see A. T. Reyes, Archaic Cyprus: A Study of the Textual and Archaeological Evidence (Oxford: Clarendon, 1994), 69-84, esp. 77-79. It is thus no longer necessary to consider Egyptian or Egyptianizing elements in Cypriot culture in the context of Egyptian political domination.

31. See Laurent Bricault, Isis, Dame des flots (Liège: C.I.P.L., 2006).

32. There are no indications for the cult of Isis going by her Egyptian name in the Greek world before the fourth century BCE (when a reference to an early fourth-century-BCE Athenian male citizen 
with the name "Isigenes" suggests some private interest in the cult; see Matthew Dillon, Girls and Women in Classical Greek Religion (New York: Routledge, 2002), 161. Similarly, we know of no Isis cults in Lydia and Etruria. Even in the Levant, at places with close historical ties to Egypt, there is precious little evidence to suggest that a cult of Isis was widespread before the Roman period. For example, references to "Isis" at Byblos may well be ascribed to an interpretatio graeca of the local deity b'lt gbl, "Lady of Byblos," rather than indicating actual worship of that particular Egyptian goddess in that important city. See A. E. Zernecke, “The Lady of the Titles: The Lady of Byblos and the Search for her 'True Name," Die Welt des Orients 43, no. 2 (2013): 232ff; Corinne Bonnet and Laurent Bricault, Quand les dieux voyagent: Cultes et mythes en mouvement dans l'espace méditérannéen antique (Geneva: Labor et Fides, 2016), 160-61; and Nassos Papalexandrou, “Are There Hybrid Visual Cultures?, Ars Orientalis 38 (2010):31-48. 